\title{
FREQUENCIES OF PREDICTED MIA ANTIGEN AMONG SOUTHERN THAI BLOOD DONORS
}

\author{
Warunrat Khosidworachet*, Supattra Mitundee**, Kamphon Intharanut*, Sasitorn Bejrachandra***, \\ Oytip Nathalang*
}

*Graduate Program, Faculty of Allied Health Sciences, Thammasat University, Pathumtani, Thailand

**Regional Blood Centre $12^{\text {th }}$ Songkhla, Thai Red Cross Society, Songkhla, Thailand

***National Blood Centre, Thai Red Cross Society, Bangkok, Thailand

\begin{abstract}
Background: The $\mathrm{Mi}^{\mathrm{a}}$ antigen (MNS7) of the MNS blood group system is clinically important in Asian populations. Anti-Mia has been implicated in hemolytic transfusion reactions and hemolytic disease of the fetus and newborn in Thai populations. However, data of this antigen frequency among southern Thais remains unknown.

Objective: This study aimed to determine and predict $\mathrm{Mi}^{\mathrm{a}}$ antigen frequencies among southern Thai blood donors and to estimate the risk of alloimmunization among Thais.

Methods: A cross-sectional study was conducted. Altogether, 400 southern and 500 central Thai blood samples were genotyped for $G Y P(B-A-B)$ and $G Y P(A-B-A)$ MNS hybrids using polymerase chain reaction with sequence-specific primer (PCR-SSP).

Results: Among them, 19 of 400 (4.45\%), and 28 of 500 (9.33\%) were positive with the set of GP. Hut, GP.HF, GP.Mur, GP.Hop, and GP.Bun. No GP.Vw phenotype was found among southern and central Thais. The predicted Mi(a+)frequency among southern Thais was significantly lower than among central and northern Thais $(p<0.05)$. Its frequency was similar to Vietnamese, Taiwanese, and Southern Han Chinese populations $(p>0.05)$ but significantly differed from Indonesian, Filipino, and Chinese (Guangzhou) populations $(p<0.05)$. The risk of $\mathrm{Mi}^{\mathrm{a}}$ alloimmunization among southern Thais was significantly lower than among both Thai groups $(p<0.05)$.

Conclusion: This constitutes the first study to report $\mathrm{Mi}(\mathrm{a}+)$ frequencies among southern Thais, supporting the estimation risk of alloimmunization and providing transfusion safety among Thai populations.
\end{abstract}

Keywords: Genotyping, MNS blood group system, Predicted Mi(a+) frequency, Southern Thais

J Southeast Asian Med Res 2022; 6: e0107

https://doi.org/10.55374/jseamed.v6i0.107

Correspondence to:

Nathalang O, Graduate Program, Faculty of Allied Health Sciences, Thammasat University, Pathumtani 12120 Thailand,

E-mail: oytipntl@hotmail.com

Received: 1 October 2021

Revised: 3 December 2021

Accepted: 6 December 2021 


\section{Introduction}

The Miltenberger (Mi) subsystem was formally classified by Cleghorn in $1966 .^{(1)}$ The antigens carried on glycophorin A (GPA), and GPB and encoded by the glycophorin genes consisted of GYPA, GYPB, and GYPE genes of the MNS blood group system. ${ }^{(2,3)}$ The formation of $G Y P(A-B-A)$ and $G Y P(B-A-B)$ hybrid genes encode various GP hybrid molecules expressed on the red cell membranes, and these hybrid GPs display an implicit phenotype profile of $\mathrm{Mi}^{\mathrm{a}}$ antigens currently established as MNS7. $\mathrm{Mi}^{\mathrm{a}}$ is an antigen illustrated in 7 hybrid GPs consisting of GP.Vw, GP.Hut, GP.HF, GP.Mur, GP.Hop, GP.Bun, and GP.Kip. ${ }^{(4)}$ These antigen frequencies are rare in Caucasians $(0.012 \%)$, African Americans ( $0 \%$ ) and Indian ( $0.2 \%)$ populations; however, higher frequencies are reported in Thai (9.7\%) and Chinese (7.3\%) populations..$^{(2,5-7)}$ Anti-Mi $^{\mathrm{a}}$ has been implicated in hemolytic transfusion reactions (HTRs), ${ }^{(8,}$ 9) hemolytic disease of the fetus and newborn (HDFN), ${ }^{(10,11)}$ and a case of hydrops fetalis. ${ }^{(12)}$ Hence, including $\mathrm{Mi}(\mathrm{a}+)$ cells in reagent red cells would noteworthy for antibody detection in Asian populations. Southern Thai Muslim populations are concentrated mainly in three provinces: Pattani, Yala and Narathiwat near the border with Malaysia, and have different ethnic origins compared with other regions of Thailand. Concerning a related study, the frequency of $\mathrm{Mi}^{\mathrm{a}}$ antigen varies among Malaysian blood donors in three ethnic groups consisting of Malay (2.08\%), Chinese (4.9\%), and Indian (3.0\%). (13) The prevalence of this antigen may involve alloantibody formation among patients regularly transfused in different ethnic groups. To date, the data of $\mathrm{Mi}^{\mathrm{a}}$ antigen frequency among southern Thai blood donors remains unknown. This study aimed to determine and predict $\mathrm{Mi}^{\mathrm{a}}$ antigen frequency among southern Thai blood donors to estimate the risk of alloimmunization in Thai populations.

\section{Methods}

This study was approved by the Committee on Human Rights Related to Research Involving Human Subjects, Thammasat University, Pathumtani, Thailand COE No. 013/2564). Informed consent was signed by all study participants. The study included EDTA-anticoagulated blood from 900 unrelated healthy Thai blood donors. In all, 400 and 500 samples were obtained from the Regional Blood Centre $12^{\text {th }}$ Songkhla, Thai Red Cross Society, Songkhla, and the National Blood Centre, Thai Red Cross Society (NBC-TRC), Bangkok, Thailand. All 400 samples were from Thai-Muslim donors living in the three southern border provinces of Pattani, Yala and Narathiwat.

Genomic DNA was extracted from peripheral blood samples using the DNeasy Blood \& Tissue Kit according to manufacturer instructions (QIAGEN GmbH, Valencia, CA, USA), then stored at $-20^{\circ} \mathrm{C}$ until used for genotyping. A PCRSSP technique to detect two MNS hybrid GPs; $G Y P(B-A-B)$ and $G Y P(A-B-A)$ were performed using two sets of primers, according to a relatedstudy. ${ }^{(14,15)}$ Control DNA of known Mi(a+) positive phenotypes was from our in house collections and GP.Vw DNA controls were provided by Dr. Genghis H. Lopez, Research and Development Laboratory, Clinical Services and Research Division, Australian Red Cross Blood Service, Brisbane, Australia. In the PCR, $1 \mu \mathrm{L}$ of genomic DNA $(50 \mathrm{ng} / \mu \mathrm{L})$ was amplified using $0.5 \mu \mathrm{L}$ of $10 \mu \mathrm{M}$ F2 primer

(5'-CCCTTTCTCAACTTCTCTTATATGC AGATAA-3') and $0.5 \mu \mathrm{L}$ of $10 \mu \mathrm{M}$ Rccgg primer (5'-GAGCAACTATTTAAAACTAAGAACA TACCGG-3') for the first set of $G Y P(B-A-B)$ detection. For the second set of $G Y P(A-B-A)$ detection, $0.5 \mu \mathrm{L}$ of $10 \mu \mathrm{M}$ F1 primer (5'-CAGCATTTCTCTAAAGGCTAAATAAGAAGATGTA-3') and $0.5 \mu \mathrm{L}$ of $10 \mu \mathrm{M}$ RIN primer (5'-CA TATGTGTCCCGTTTGTGCA-3'). Moreover, $0.5 \mu \mathrm{L}$ of $6 \mu \mathrm{MHGH}-434-\mathrm{F}$ primer (5'-TGC CTTCCCAACCATTCCCTT A-3') and $0.5 \mu \mathrm{L}$, $6 \mu \mathrm{M}$ of HGH-434-R(5'-CCACTCACGGATT TCTGTTGTGTTTC-3') primer were included in both sets of $G Y P(B-A-B)$ and $G Y P(A-B-A)$ detections. PCR of each MNS hybrid GP detection was performed using $5 \mu \mathrm{L}$ of $2 \mathrm{X}$ PCR reaction mixture (Green Hot Start PCR Master Mix, Biotechrabbit GmbH, Hennigsdorf, Germany), and $2 \mu \mathrm{L}$ of distilled water added to a final volume of $10 \mu \mathrm{L}$.

PCR amplification of two sets was performed in a T100 Thermal cycler (Bio-Rad Laboratories, Inc., USA). For the first set of $G Y P(B-A-B)$ 
detection, the cycling parameters for the PCR program consisted of 1 cycle at $95^{\circ} \mathrm{C}$ for $5 \mathrm{~min}$, followed by 30 cycles at $95^{\circ} \mathrm{C}$ for $30 \mathrm{sec}, 62^{\circ} \mathrm{C}$ for $40 \mathrm{sec} 72^{\circ} \mathrm{C}$ for $30 \mathrm{sec}$, with a final extension at $72^{\circ} \mathrm{C}$ for $5 \mathrm{~min}$. For the second set of $G Y P(A-B-A)$ detection, the cycling parameters for the PCR program consisted of 10 cycles at $95^{\circ} \mathrm{C}$ for $30 \mathrm{sec}$, followed by 10 cycles at $95^{\circ} \mathrm{C}$ for $10 \mathrm{sec}, 64^{\circ} \mathrm{C}$ for $1 \mathrm{~min}, 30$ cycles at $95^{\circ} \mathrm{C}$ for $10 \mathrm{sec}, 61^{\circ} \mathrm{C}$ for $50 \mathrm{sec}, 72^{\circ} \mathrm{C}$ for $30 \mathrm{sec}$, with a final extension at $72^{\circ} \mathrm{C}$ for $5 \mathrm{~min}$. PCR products were electrophoresed at $100 \mathrm{~V}$ with a $1.5 \%$ agarose gel containing 10,000X fluorescent DNA gel stain (SYBR Safe DNA gel stain) using 1X TBE buffer. Products were visualized under a blue-light transilluminator.

Altogether, 900 samples of Thai blood donors including 400 and 500 from southern and central Thais were employed for $G Y P(A-B-A)$ and $G Y P$ $(B-A-B)$ hybrid detections using PCR-SSP.

\section{Statistical analysis}

The frequencies of predicted $\mathrm{Mi}(\mathrm{a}+)$ were calculated using the gene counting method.
The differences in $\operatorname{Mi}\left(\mathrm{a}^{+}\right)$frequencies between southern Thai and other populations were compared using a chi-square test of homogeneity. In addition, the risk estimation of $\mathrm{Mi}^{\mathrm{a}}$ alloimmunization was obtained by multiplying the probability of having a predicted $\mathrm{Mi}(\mathrm{a}-)$ phenotype frequency by the probability of having a predicted $\mathrm{Mi}\left(\mathrm{a}^{+}\right)$ phenotype frequency. All statistical analyses were conducted using SPSS, Version 16.0 (SPSS Inc., Chicago, IL, USA). A $p$-value less than 0.05 was considered statistically significant.

\section{Results}

The PCR-SSP results of MNS hybrid GP detections are shown in Figure 1. The $G Y P(B-A-B)$ hybrids of $G Y P^{*} H u t, G Y P^{*} M u r, G Y P^{*} H o p$, $G Y P^{*} B u n$, and $G Y P^{*} H F$ were amplified with the first set of primers (the product size of 148 or $151 \mathrm{bp})$, whereas $G Y P^{*} V w$ of the $G Y P(A-B-A)$ hybrids was amplified using the second set of primers (the product size of $296 \mathrm{bp}$ ). The DNA controls were also tested using these two sets of primers, and the results agreed.

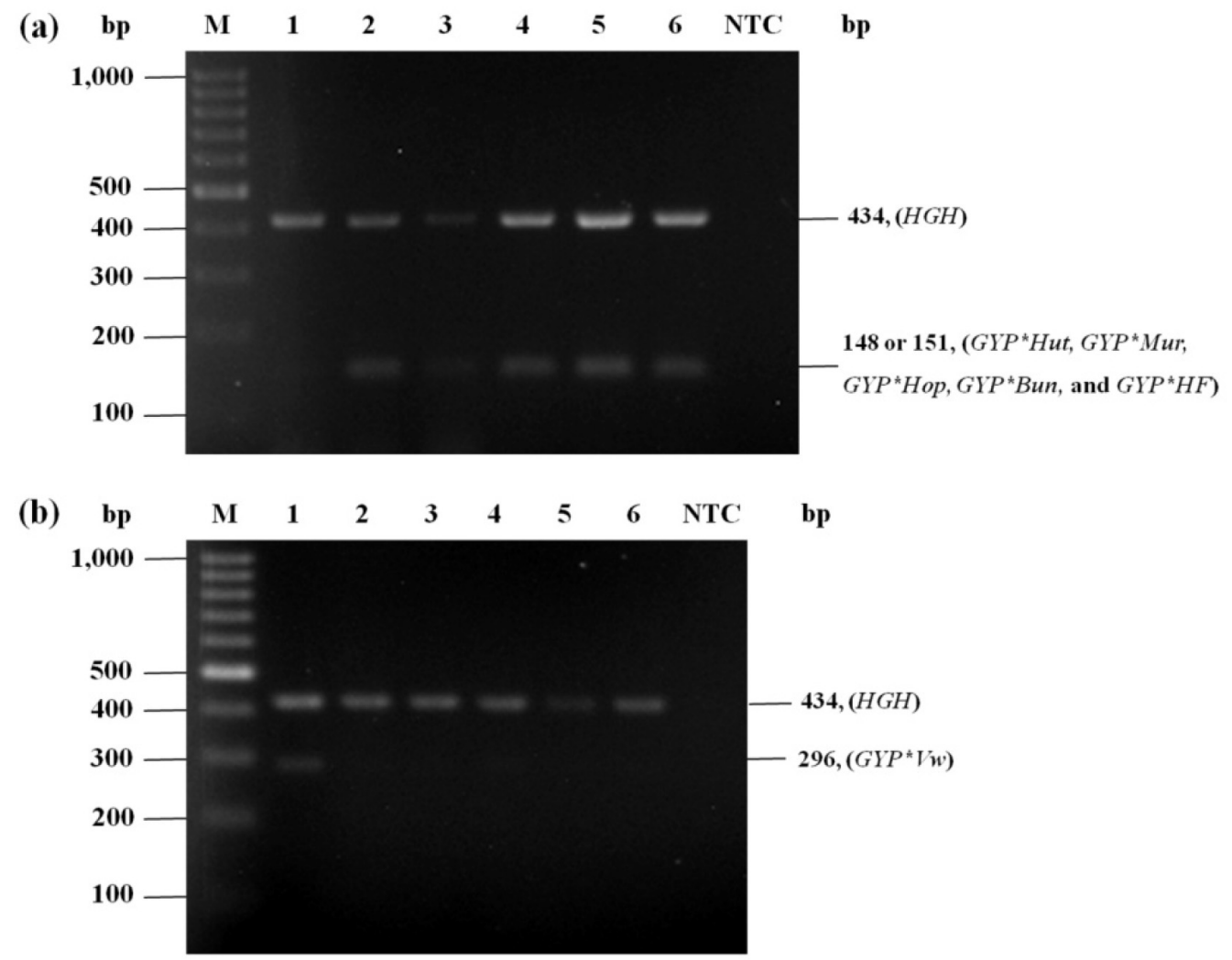

Figure 1. PCR-SSP results of MNS hybrid GP detections, (a) PCR products in Lanes 1-6 were amplified using the first set of primers, amplifying the fragments of the $G Y P(B-A-B)$ hybrids of $G Y P^{*} H u t$, $G Y P^{*} M u r, G Y P^{*} H o p, G Y P^{*} B u n$, and $G Y P^{*} H F$. (b) PCR products in Lanes 1-6 were amplified the second set of primers, amplifying the fragment of the $G Y P(A-B-A)$ hybrid of $G Y P^{*} V w$. Lane NTC was the negative control (nontemplate control). Lane M: molecular weight 100-bp DNA Ladder. 
Table 1. Occurrence of $G Y P(B-A-B)$ hybrids in Asian populations determined by PCR-based assays

\begin{tabular}{|c|c|c|c|c|c|}
\hline \multirow{2}{*}{ Population } & \multirow{2}{*}{ Number } & \multicolumn{2}{|c|}{$G Y P(B-A-B)$ hybrids } & \multirow{2}{*}{$\chi^{2}$} & \multirow{2}{*}{$p$-value } \\
\hline & & $\operatorname{Mi}(\mathbf{a}+)$ & Mi(a-) & & \\
\hline Southern Thai (This study) & 400 & 19 & 381 & & \\
\hline Central Thai (This study) & 500 & 51 & 449 & 9.202 & 0.002 \\
\hline Northern Thai ${ }^{(15)}$ & 300 & 67 & 233 & 49.183 & $<0.001$ \\
\hline Vietnamese ${ }^{(16)}$ & 160 & 10 & 150 & 0.524 & 0.469 \\
\hline Taiwanese $^{(16)}$ & 167 & 7 & 160 & 0.084 & 0.772 \\
\hline Indonesian ${ }^{(16)}$ & 285 & 5 & 280 & 4.417 & 0.035 \\
\hline Filipino $^{(16)}$ & 262 & 20 & 242 & 179.851 & $<0.001$ \\
\hline Southern Han Chinese ${ }^{(17)}$ & 3,104 & 201 & 2,903 & 1.792 & 0.181 \\
\hline Chinese (Guangzhou) $)^{(18)}$ & 528 & 51 & 477 & 7.864 & 0.005 \\
\hline
\end{tabular}

Table 2. Estimations of risk for $\mathrm{Mi}^{\mathrm{a}}$ alloimmunization in Thai populations

The frequencies of

\begin{tabular}{|c|c|c|c|c|}
\hline \multirow[t]{2}{*}{ Population } & \multirow[t]{2}{*}{ Number } & \multicolumn{2}{|c|}{ predicted $\mathrm{Mi}^{\mathrm{a}}$ phenotype } & \multirow{2}{*}{$\begin{array}{l}\text { Risk of } \mathrm{Mi}^{\mathrm{a}} \\
\text { alloimmunization }\end{array}$} \\
\hline & & Negative & Positive & \\
\hline Southern Thai & 400 & 0.953 & 0.047 & 0.045 \\
\hline Central Thai & 500 & 0.898 & 0.102 & $0.092^{*}$ \\
\hline Northern Thai ${ }^{(15)}$ & 300 & 0.777 & 0.223 & $0.173^{*}$ \\
\hline
\end{tabular}

$* p<0.05$

Among 400 southern and 500 central Thai blood donors, $19(4.45 \%)$, and 28 (9.33\%) were positive only with the set of primers specific for GP.Hut, GP.HF, GP.Mur, GP.Hop, and GP.Bun. No GP.Vw phenotype was identified by PCRSSP technique among southern and central Thais. Regarding the positive results of the MNS hybrid GPs by PCR-SSP, the predicted Mi $(\mathrm{a}+)$ frequency among southern Thais was significantly lower than that among central $(p=0.002)$ and northern Thais $(p<0.001) .{ }^{(15)}$ The $\operatorname{Mi}(\mathrm{a}+)$ frequency between southern Thais and other populations was compared. The frequencies were similar to Vietnamese, Taiwanese, and Southern Han Chinese populations $(p>0.05) .{ }^{(16,17)}$ On the contrary, its frequency significantly differed from Indonesian, Filipino, and Chinese (Guangzhou) populations $(p<0.05) .{ }^{(16,18)}$, as shown in Table 1 . In addition, the risk of $\mathrm{Mi}^{\text {a }}$ alloimmunization among southern Thais was significantly lower than those among central and northern Thais $(p<0.05)$, as shown in Table 2.

\section{Discussion}

In Thailand, blood group allele frequencies have been studied among central, northern and southern Thais. The $D I^{*} A$ allele (predicted $\mathrm{Di}^{\mathrm{a}}$ antigen) was significantly lower among southern Thais, while the $J K^{*} 01$ allele (predicted $\mathrm{Jk}^{\mathrm{a}}$ antigen) and $K E L^{*} 01$ allele (predicted $\mathrm{K}$ antigen) were significantly higher among southern Thais than among central and northern Thais. ${ }^{(19)}$ However, the $\mathrm{Mi}^{\mathrm{a}}$ frequencies have not yet been reported in southern Thailand. This study constitutes the first to identify the predicted $\mathrm{Mi}^{\mathrm{a}}$ frequencies in Thai Muslim populations, which have their own religion, culture and sustainable lifestyle.

Regarding the genotyping of MNS hybrid GP results using PCR-SSP among the four types; GP.Mur, GP.Hop, GP.Bun, and GP.HF of GYP 
( $B-A-B)$ hybrids, GP.Mur is commonly found in Asian and Australian populations. ${ }^{(4,14,16-18)}$ Notably, GP.Vw of the $G Y P(A-B-A)$ hybrids was not found among southern and central Thais, similar to related studies in Thai and other Asian populations. ${ }^{(14,16-18)}$ The predicted $\mathrm{Mi}(\mathrm{a}+)$ phenotype among southern Thais (4.8\%) is closely related to Chinese-Malaysians (4.9\%) but unrelated to Malay and Indian Malaysians $\left(2.08 \%\right.$ and $3.0 \%$, respectively). ${ }^{(13)}$ Even though the probability of finding the $\mathrm{Mi}(\mathrm{a}+)$ phenotype among southern Thais is lower than among central and northern Thais, anti-E and anti-Mi ${ }^{\mathrm{a}}$ are frequently found among southern Thai patients requiring repeated transfusions. ${ }^{(20,21)}$ Hence, the use of PCR-based assay to predict $\mathrm{Mi}^{\mathrm{a}}$ antigen in blood donors and chronically transfused patients would be helpful to reduce alloimmunization risks and the above-mentioned adverse events. This study confirmed that it would pose no difficulty to find $\mathrm{Mi}^{\mathrm{a}}$ antigen-negative donors for Thai patients with anti-Mia except among chronically transfused patients with multiple antibodies including anti-Mia . The possibility of finding compatible donor blood in complex cases caused by multiple alloantibodies may be more difficult concerning potential donors with a compatible blood type. Concerning patients requiring repeated transfusions such as thalassemia, cancer, and chronic renal diseases, performing $\mathrm{Mi}^{\mathrm{a}}$ antigen typing is suggested before transfusion therapy and $\mathrm{Mi}^{\mathrm{a}}$-compatible donor (s) should be provided to patients. In concordance with the Clinical Practice Guidelines for diagnosis and management of thalassemia, the antigen typing of $\mathrm{Rh}(\mathrm{C}, \mathrm{c}, \mathrm{E}, \mathrm{e})$ and $\mathrm{MNS} 7\left(\mathrm{Mi}^{\mathrm{a}}\right)$ is minimally required before the first transfusion. (22) This particular blood group antigen frequency could support not only determining genetic variation but also enhancing the characterization of Thai populations, especially in blood transfusion therapy.

\section{Conclusion}

This study is the first to report $\mathrm{Mi}(\mathrm{a}+)$ frequencies among southern Thai blood donors. This finding is helpful to estimate the risk of alloimmunization and to provide transfusion safety in Thai populations.

\section{Disclosures}

The authors declare they have no conflicts of interest.

\section{Acknowledgement}

The authors gratefully acknowledge the financial support provided by the National Research Council of Thailand.

\section{References}

1. Cleghorn TE. A memorandum on the Miltenberger blood groups. Vox Sang 1966; 1: 219-22.

2. Daniels G. Human blood groups, $3^{\text {rd }}$ ed. Malden, MA, Blackwell Science, 2013.

3. Reid ME, Lomas-Francis C, Olsson M. The blood group antigen factsbook, $3^{\text {rd }}$ ed. New York, Academic Press, 2012.

4. Lopez GH, Wilson B, Turner RM, Millard GM, Roots NM, Liew YW, et al. Frequency of $\mathrm{Mi}^{\mathrm{a}}$ (MNS7) and classification of $\mathrm{Mi}^{\mathrm{a}}$-positive hybrid glycophorins in an Australian blood donor population. Transfus Med Hemother 2020; 47: 279-86.

5. Makroo RN, Bhatia A, Chowdhry M, Rosamma NL, Karna P. Frequency of Mi(a) antigen: A pilot study among blood donors. Indian J Med Res 2016; 143: 63-5.

6. Chandanyingyong D, Pejrachandra S. Studies on the Miltenberger complex frequency in Thailand and family studies. Vox Sang 1965; 28: 152-5.

7. Chen V, Halverson G, Wasniowska K, Lisowska E, Chen J, Moulds M, Reid ME. Direct evidence for the existence of Miltenberger antigen. Vox Sang 2001; 80: 230-3.

8. Chiewsilp P, Yodpornpin W, Cherdchai S. Delayed hemolytic transfusion reaction due to anti-Mi ${ }^{\text {a }}$ [in Thai]. Thai J Hematol Transfus 1996; 6: 289-90.

9. Lin M, Broadberry RE. An intravascular hemolytic transfusion reaction due to anti'Mi(a)' in Taiwan. Vox Sang 1994; 67: 320.

10. Cheng G, Hui CH, Lam CK, Hal SY, Wong L, Mak KH, Lin CK. Haemolytic transfusion reactions due to Mi-antibodies; need to include MiltenbergerIII positive cells in pre-transfusion antibody screening in Hong Kong. Clin Lab Haematol 1995; 17: 183-4. 
11. Lin CK, Mak KH, Szeto SC, Poon KH, Yuen CMY, Chan NK, et al. First case of haemolytic disease of the newborn due to anti-Mur in Hong Kong. Clin Lab Haematol 1996; 18: 19-22.

12. Wu KH, Chang JG, Lin M, Shih MC, Lin $\mathrm{HC}$, Lee CC, et al. Hydrops foetalis caused by anti-Mur in first pregnancy--a case report. Transfus Med 2002; 12: 325-7.

13. Prathiba R, Lopez CG, Usin FM. The prevalence of GP Mur and anti- "Mia" in a tertiary hospital in Peninsula Malaysia. Malays J Pathol 2002; 24: 95-8.

14. Palacajornsuk $P$, Nathalang O, Tantimavanich S, Bejrachandra S, Reid ME. Detection of MNS hybrid molecules in the Thai population using PCR-SSP technique. Transfus Med 2007; 17: 169-74.

15. Intharanut $\mathrm{K}$, Bejrachandra $\mathrm{S}$, Nathalang $\mathrm{S}$, Leetrakool N, Nathalang O. Red cell genotyping by multiplex PCR identifies antigen-matched blood units for transfusion-dependent Thai patients. Transfus Med Hemother 2017; 44: 358-64.

16. K, Lin YC, Chao HP, Lee TY, Lin M, Chan YS. Assessing the frequencies of GP.Mur (Mi.III) in several Southeast Asian populations by PCR typing. Transfus Apher Sci 2013; 49: 370-1.

17. Wei L, Lopez GH, Zhang Y, Wen J, Wang Z, $\mathrm{Fu} \mathrm{Y}$, et al. Genotyping analysis of MNS blood group GP(B-A-B) hybrid glycophorins in the Chinese Southern Han population using a high-resolution melting assay. Transfusion 2018; 58: 1763-71.

18. Wei L, Shan ZG, Flower RL, Wang Z, Wen JZ, Luo GP, et al. The distribution of MNS hybrid glycophorins with Mur antigen expression in Chinese donors including identification of a novel GYP.Bun allele. Vox Sang 2016; 111: 308-14.

19. Nathalang O. Red cell genotyping in Thailand: trends for blood transfusion in Asian populations. VOXS 2020; 15: 310-4.

20. Promwong C, Siammai S, Hassarin S, Buakaew J, Yeela T, Soisangwan P, et al. Frequencies and specificities of red cell alloantibodies in the Southern Thai population. Asian J Transfus Sci 2013; 7: 16-20.

21. Kupatawintu P, Emthip M, Sungnoon D, O-vataga P, Manakul V, Limtamaporn S, et al. Unexpected antibodies of patients, blood samples sent for testing at NBC. TRCS [in Thai]. J Hematol Transfus Med 2010; 20: 255-62.

22. Fucharoen S, Tanphaichitr VS, Torcharus K, Viprakasit V, Mekaewkunchorn A: Clinical practice guidelines for diagnosis and management of thalassemia syndromes. $1^{\text {st }} \mathrm{ed}$, (in Thai) Bangkok, P.A. Living, 2014. 